\title{
Dexamethasone and Fumaric Acid Ester Conjugate Synergistically Inhibits Inflammation and NF-KB in Macrophages
}

Christopher J. Genito, ${ }^{1}$ Meital Eckshtain-Levi, ${ }^{2}$ Zayda L. Piedra-Quintero, ${ }^{3}$ Sai Archana Krovi, ${ }^{2}$ Abriana Kroboth, ${ }^{3}$ Rebeca T. Stiepel, ${ }^{2}$ Mireia Guerau-de-Arellano, ${ }^{3}$ Eric M. Bachelder, ${ }^{2}$ Kristy M. Ainslie ${ }^{1,2,4, *}$

${ }^{1}$ Department of Microbiology and Immunology, School of Medicine, University of North Carolina at Chapel Hill, Chapel Hill, NC 27599, USA.

2Division of Pharmacoengineering and Molecular Pharmaceutics, Eshelman School of Pharmacy, University of North Carolina at Chapel Hill, Chapel Hill, NC 27599, USA.

${ }^{3}$ Division of Medical Laboratory Science, School of Health and Rehabilitation Sciences, College of Medicine, Wexner Medical Center, The Ohio State University, Columbus, OH 43210, USA.

${ }^{4}$ Joint Department of Biomedical Engineering, University of North Carolina at Chapel Hill and North Carolina State University 27599 , USA.

\section{${ }^{*}$ Corresponding Author Address:}

Kristy M. Ainslie

Professor and Vice Chair

Division of Pharmacoengineering and Molecular Pharmaceutics

UNC Eshelman School of Pharmacy

4211 Marsico Hall, 125 Mason Farm Road

Chapel Hill, NC 27599, United States

ainsliek@email.unc.edu

\section{SUPPORTING METHODS}

Determination of cytotoxicity. After $24 \mathrm{~h}$ treatment, treatment-related cytotoxicity was determined in cell supernatants using the Invitrogen ${ }^{\mathrm{TM}}$ CyQUANT ${ }^{\mathrm{TM}}$ LDH Cytotoxicity Assay kit (Life Technologies, Eugene, OR) and performed using the manufacturer's protocol. Cell viability is normalized to cells having received LPS but no drug treatment ( $0 \%$ cytotoxicity) and cells completely lysed at the time of analysis $(100 \%$ cytotoxicity).

Flow cytometry. Monocyte-derived macrophages from human PBMCs were characterized by flow cytometry, as previously described. ${ }^{1}$ Surface markers analyzed include CD14 (clone 61D3, PerCP/cy5.5, eBioscience), CD11b (clone ICRF44, APC, BioLegend), CD38 (clone HIT2, FITC, BioLegend), and CD40 (clone 5C3, eFluor 8 450, eBioscience). 

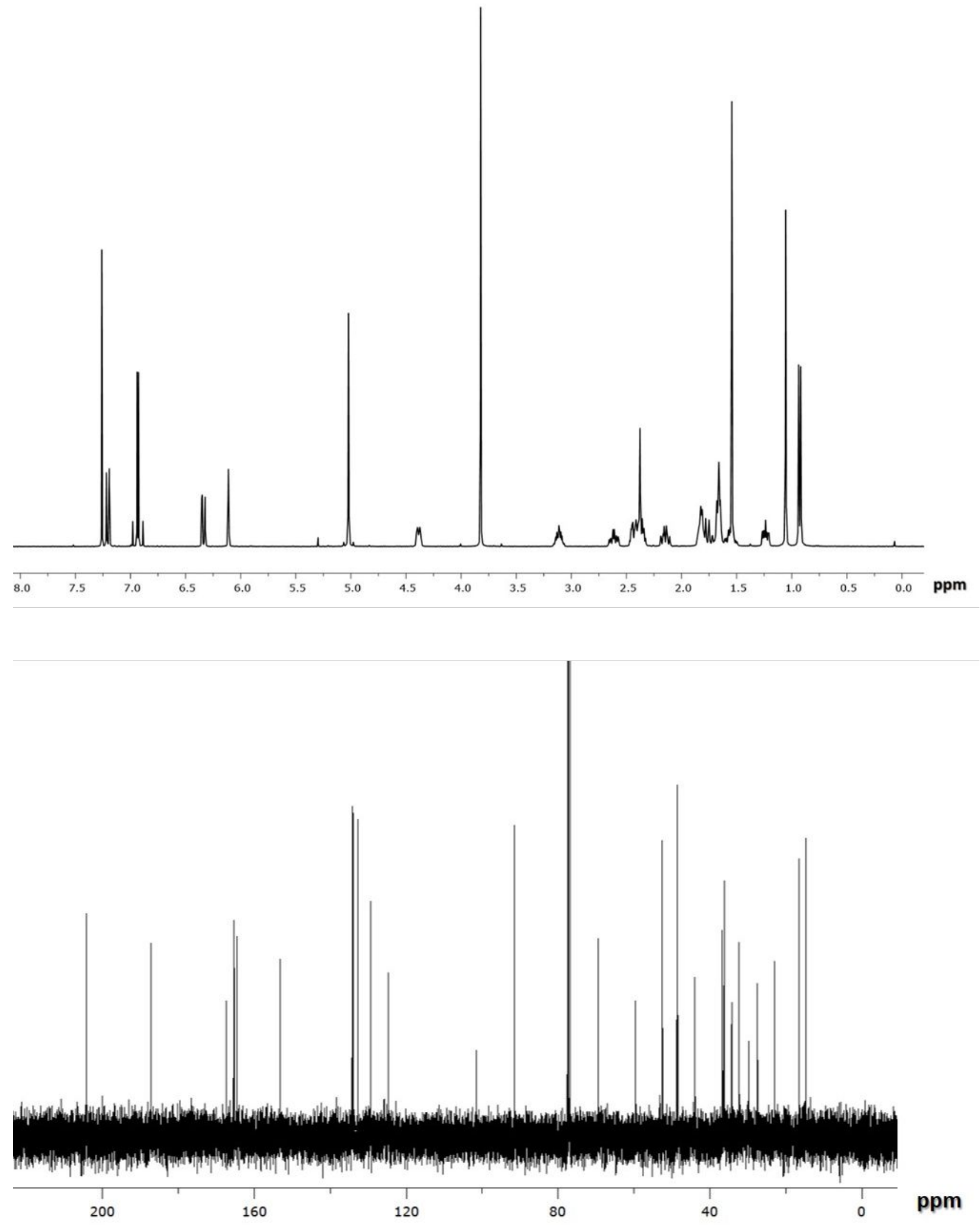

Figure S1. NMR spectrograms of dexamethasone-monomethyl fumarate conjugate.(A) ${ }^{1} \mathrm{H} \mathrm{NMR}\left(\mathrm{CDCl}_{3}\right.$, $400 \mathrm{MHz}, \delta \mathrm{ppm}): 7.18(1 \mathrm{H}, \mathrm{CH}=\mathrm{CH}$ in 6 member ring), 6.96-6.87 $(2 \mathrm{H}, \mathrm{CH}=\mathrm{CH}), 6.3(1 \mathrm{H}, \mathrm{CH}=\mathrm{CH}$ in 6 member ring), $6.1\left(1 \mathrm{H}, \mathrm{CH}=\mathrm{C}\right.$ in 6 member ring), $5\left(2 \mathrm{H}, \mathrm{C}=\mathrm{COCH}_{2} \mathrm{O}\right), 4.3(1 \mathrm{H}, \mathrm{CHOH}), 3.8\left(3 \mathrm{H}, \mathrm{OCH}_{3}\right)$, 
3.13-3.06 (2H, CH= $\mathrm{CCH}_{2} \mathrm{CH}_{2}$ in 6-membered ring), 2.64-2.55 (2H, $\mathrm{CHCH}_{2} \mathrm{CHCH}_{3}$ in 5-membered ring), 2.45-2.31 (2H, CH= $\mathrm{CCH}_{2} \mathrm{CH}_{2}$ in 6-membered ring), 2.17-2.09 $(1 \mathrm{H}, \mathrm{CFCH}), 1.86-1.57\left(1 \mathrm{H}, \mathrm{CCHCH}_{3}\right.$ in 5membered ring), $1.54\left(3 \mathrm{H}, \mathrm{CH}=\mathrm{CHCCH}_{3}\right), 1.26-1.19\left(2 \mathrm{H}, \mathrm{CHCH}_{2} \mathrm{CCH}_{3}\right.$ in 6-membered ring), $1.02(1 \mathrm{H}$, $\left.\mathrm{CHCHCCH}_{3}\right), 0.89\left(3 \mathrm{H}, \mathrm{CH}_{3}\right.$ in 6-membered ring), $0.88\left(3 \mathrm{H}, \mathrm{CH}_{3}\right.$ in 5-membered ring). (B) ${ }^{13} \mathrm{C} N M R$ $\left(\mathrm{CDCl}_{3}, 100 \mathrm{MHz}, \delta \mathrm{ppm}\right): 204.2\left(\mathrm{C}=\mathrm{OCH}_{2} \mathrm{C}\right), 187.2$ ( $\mathrm{C}=\mathrm{O}$ in 6-membered ring), $167.3\left(\mathrm{C}=\mathrm{OOCH}_{3}\right), 165.2$ $(\mathrm{C}=\mathrm{CH}$ in 6-membered ring), $164.5(\mathrm{C}=\mathrm{OCH}=\mathrm{CH}), 153.1(\mathrm{CH}=\mathrm{CHC}=\mathrm{O}$ in 6-membered ring), 133.9, 132.8 $(\mathrm{CH}=\mathrm{CHC}=\mathrm{OO}), 129.4(\mathrm{CH}=\mathrm{CHC}=\mathrm{O}$ in 6-membered ring), $124.7(\mathrm{C}=\mathrm{OCH}=\mathrm{C}$ in 6-membered ring), 101.4 (CF), 91.3 ( $\mathrm{COH}$ in 5-membered ring), 72.1 ( $\mathrm{COH}$ in 6-membered ring), $69.3\left(\mathrm{C}=\mathrm{OCH}_{2} \mathrm{O}\right), 52.2$ $\left(\mathrm{OCH}_{3}\right), 48.4\left(\mathrm{CFCCH}_{3}\right), 43.8\left(\mathrm{CH}_{3} \mathrm{CCH}\right), 36.7\left(\mathrm{CCH}_{3}\right.$ in 5-membered ring), $35.9\left(\mathrm{CH}_{2} \mathrm{CHOH}\right.$ in 6membered ring), 33.9 (CHCF), $32.2\left(\mathrm{CH}_{2} \mathrm{CHCH}_{3}\right.$ in 5-membered ring), $29.6\left(\mathrm{CH}_{2} \mathrm{CH}_{2} \mathrm{CH}\right.$ in 6-membered ring), $27.5\left(\mathrm{CH}_{2} \mathrm{CH}_{2} \mathrm{CH}\right.$ in 6-membered ring), $22.9(\mathrm{CFCCH}), 16.5\left(\mathrm{CH}_{3}\right.$ in 6-membered ring), $14.7\left(\mathrm{CH}_{3}\right.$ in 5-membered ring).

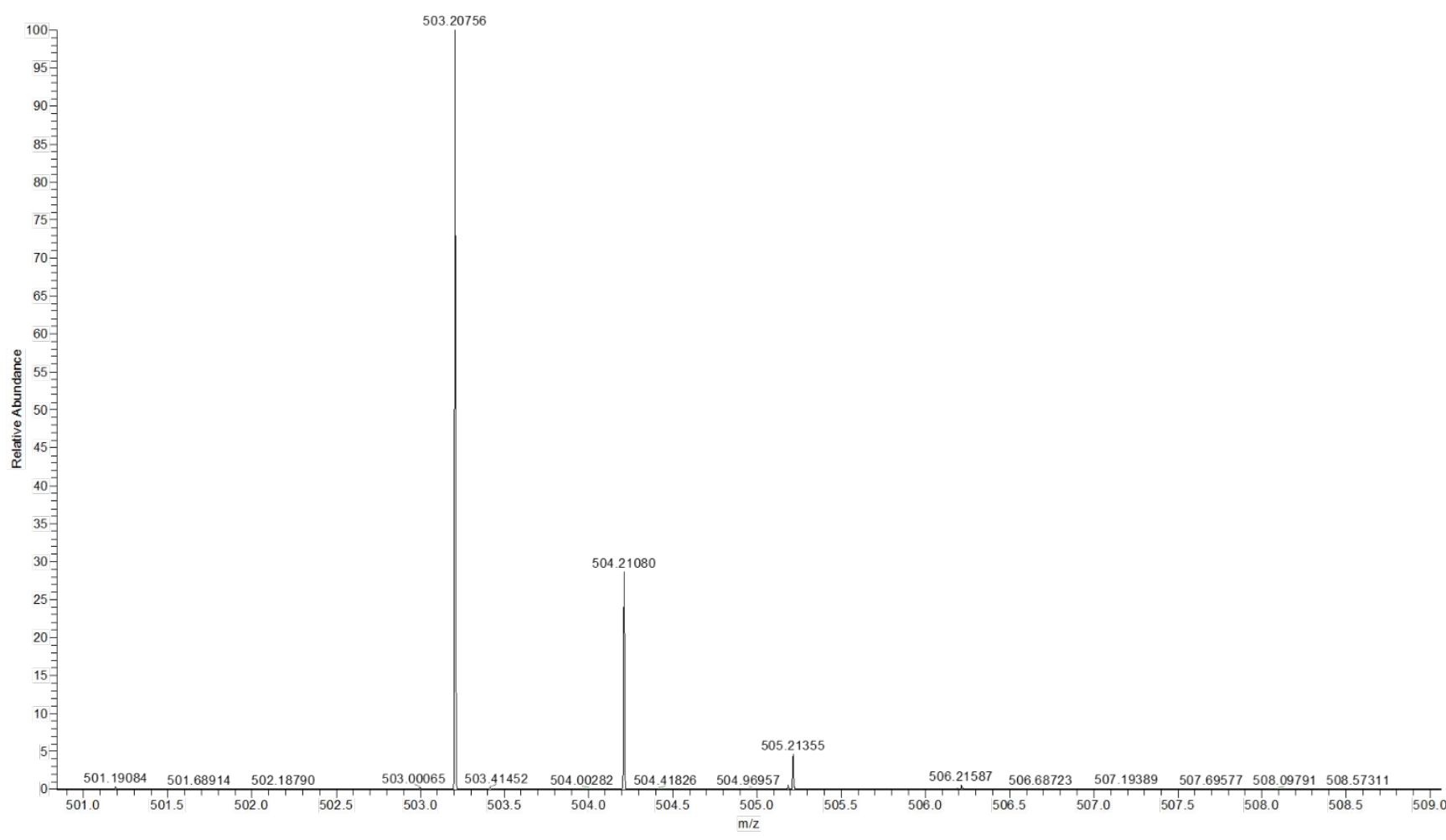

Figure S2. Electrospray ionization-mass spectrum of dexamethasone-monomethyl fumarate conjugate. $m / z$ calculated for $\mathrm{C}_{27} \mathrm{H}_{33} \mathrm{FO}_{8}[\mathrm{M}-\mathrm{H}]^{-}:$503.55. Found: 503.21. 
A

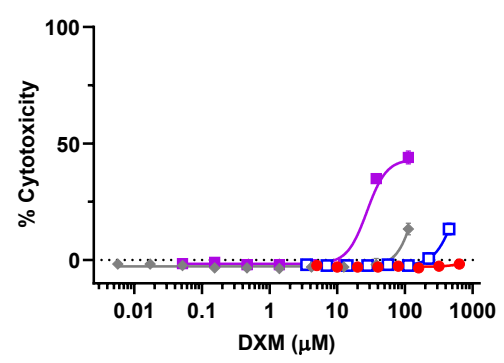

C

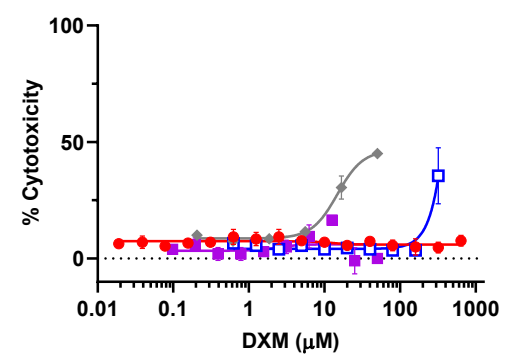

B

$\rightarrow$ DXM alone

$\rightarrow$ 1:1 DXM:DMF

마- 1:1 DXM:MMF, unconjugated

- 1:1 DXM:MMF, conjugated

- DXM alone

$\rightarrow$ 1:1 DXM:DMF

마 1:1 DXM:MMF, unconjugated

$\rightarrow$ 1:1 DXM:MMF, conjugated

Figure S3. Impact of monomethyl fumarate (MMF) and dexamethasone (DXM) conjugate on murine macrophage cytotoxicity. Conjugated DXM and MMF were compared to unconjugated DXM and MMF or dimethyl fumarate (DMF) in a 1:1 molar ratio. Data is normalized to untreated cells. Cytotoxicity of murine macrophages relative to (A) DXM and (B) FAE content. Cytotoxicity of THP-1 monocytes relative to (C) DXM and (D) FAE content. Data is presented as mean \pm standard deviation and represent two individual experiments. 


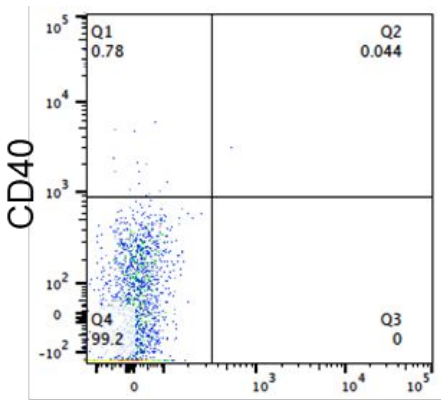

Isotype
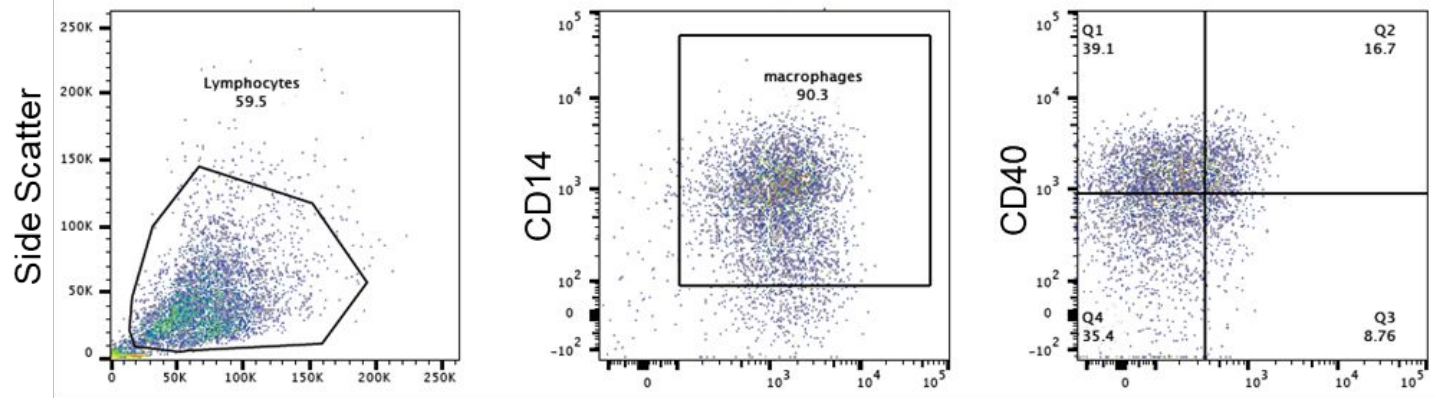

Unstimulated

Macrophages
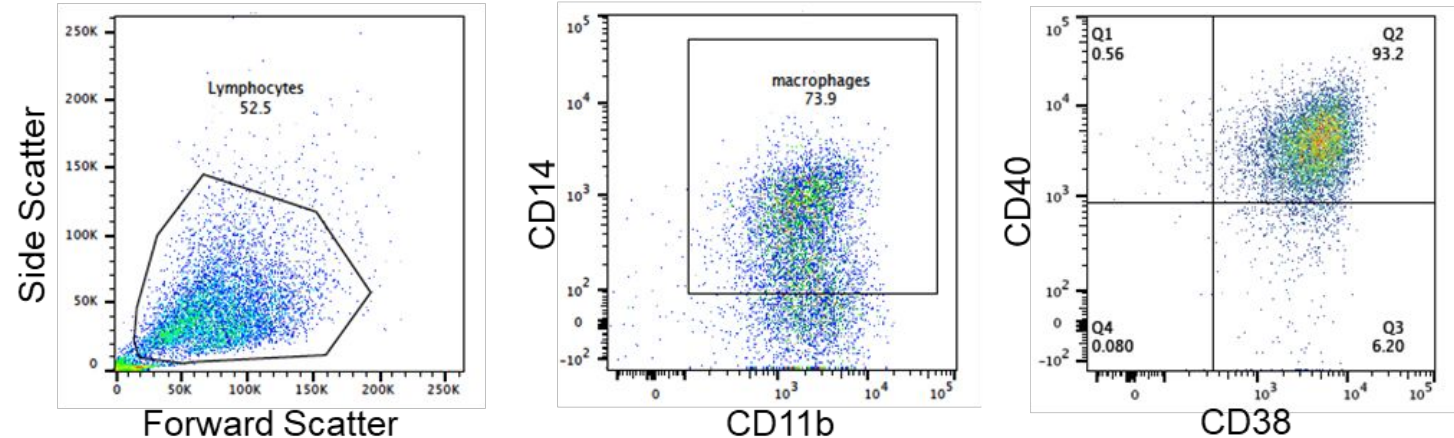

Inflammatory

Macrophages

Figure S4. Characterization of Human Monocyte-Derived Macrophages. Activated human monocytederived macrophages were assessed for expression of CD14, CD11b, CD40 and CD38 by flow cytometry. 
A

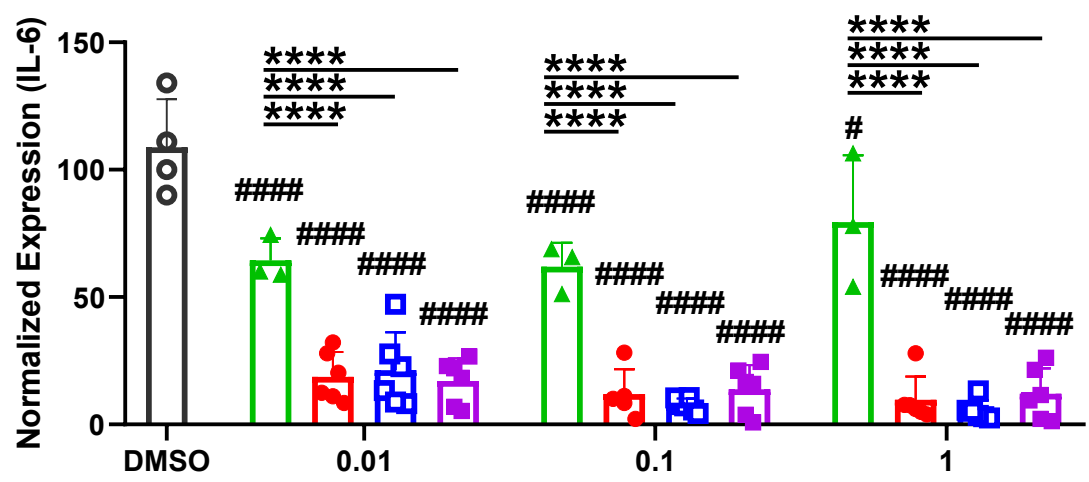

- DMSO

$\triangle$ MMF alone

- DXM alone

口 1:1 DXM:MMF, unconjugated

- 1:1 DXM:MMF, conjugated

Relative Concentration $(\mu \mathrm{M})$

B

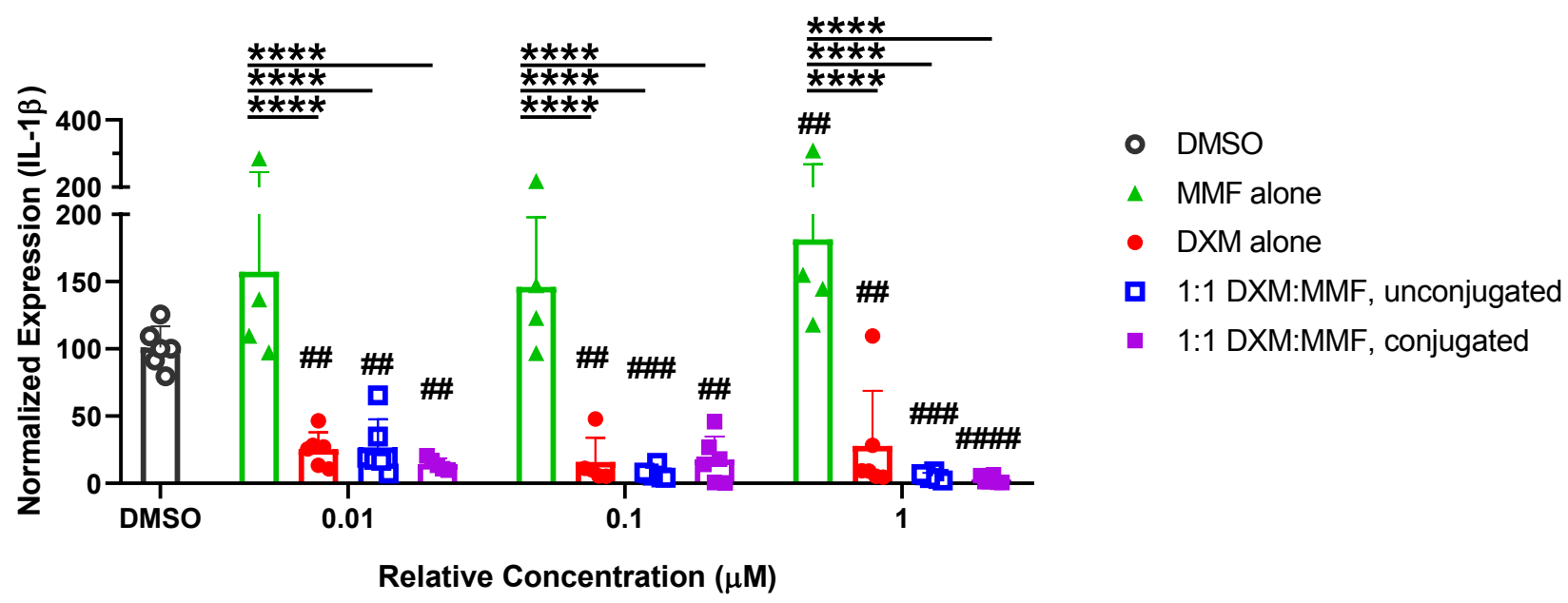

Figure S5. Inhibition of IL-6 and IL-1 $\beta$ production from human macrophages with treatment by dexamethasone (DXM) and monomethyl fumarate (MMF). DXM and MMF were used to treat human monocyte-derived macrophages. Conjugated and unconjugated DXM and MMF were used to treat activated cells, which were assessed for $(\mathbf{A}) \mathrm{IL}-6$ and $(\mathbf{B}) \mathrm{IL}-1 \beta$ mRNA. Expression is normalized to

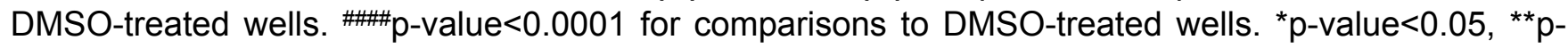
value $<0.01,{ }^{* * *} p$-value $<0.001$, and ${ }^{* * *} p$-value $<0.0001$. Data is presented as mean \pm standard deviation and represent two individual experiments. 
A
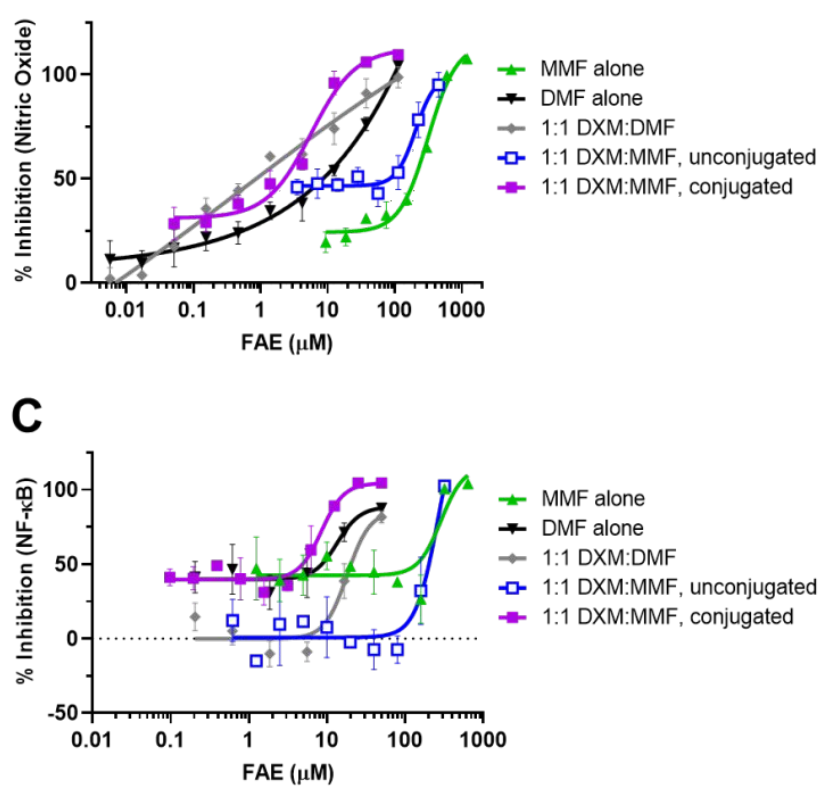

B

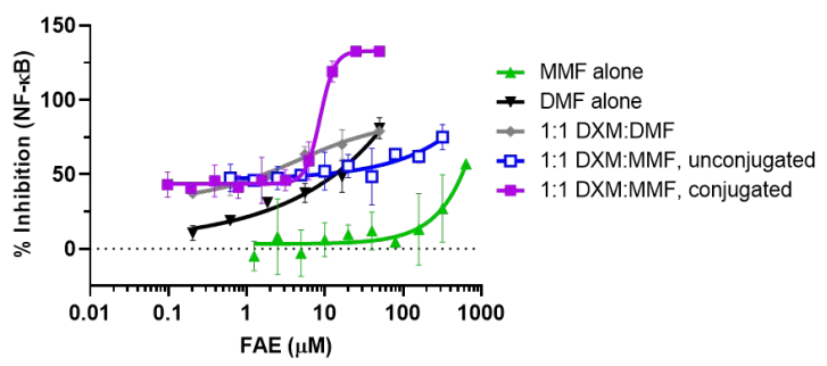

Figure S6. Conjugated dexamethasone (DXM) and monomethyl fumarate (MMF) in comparison to the unconjugated combination of DXM and dimethyl fumarate (DMF). DXM or fumaric acid esters MMF or DMF, were used to treat activated (A) murine macrophages, (B) NF-kB luciferase reporter murine macrophages or (C) macrophages derived from NF-kB luciferase reporter THP-1 human monocytes. Inhibition is normalized to untreated cells. Data is presented as mean \pm standard deviation and represent two individual experiments.

\section{SUPPORTING REFERENCES}

(1) Amici, S. A., Young, N. A., Narvaez-Miranda, J., Jablonski, K. A., Arcos, J., Rosas, L., Papenfuss, T. L., Torrelles, J. B., Jarjour, W. N., and Guerau-de-Arellano, M. (2018) CD38 Is Robustly Induced in Human Macrophages and Monocytes in Inflammatory Conditions. Front Immunol 9 , 1593. 